\title{
Infused virtue as virtue simply: the centrality of the Augustinian definition in Summa theologiae I/2.55-67
}

\section{Robert Miner}

Department of Philosophy, Baylor University, Waco, TX 76798

Robert_Miner@baylor.edu

\begin{abstract}
'Virtue is a good quality of the mind, by which one lives rightly, which no one uses badly, which God works in us without us.' Thomas Aquinas quotes this 'Augustinian' definition near the beginning of his treatment of virtue in general. Because it fails to apply to acquired virtues, some conclude that Aquinas presents this definition only to set it aside. Against such interpretations, I demonstrate that Thomas' use of the definition is the key to understanding the treatment of virtue at Summa 1/2.55-63. First, I show why Thomas places the definition where he does, at the end of question 55. Second, I show that the definition is not peripheral but rather discloses the inner logic of his treatment of virtue. Finally, I show that for the reader who grasps this inner logic, the conclusion drawn explicitly at Question 65 - that only infused virtue is virtue simply - is revealing but not surprising.
\end{abstract}

Keywords: Thomas Aquinas, Augustine, ethics, infused virtue, Peter Lombard, virtue

At the centre of Summa theologiae I/2, the reader finds a comprehensive but sometimes vexing treatment of virtue in questions 55-67. Among its puzzles is the handling of a definition of virtue taken from Peter Lombard's Sentences. Assembled mostly from Augustinian texts, particularly the nineteenth chapter of De libero arbitrio, the definition reads: 'Virtue is a good quality of the mind, by which one lives rightly, which no one uses badly, which God works in us without us' $(55.4 \mathrm{co}) .{ }^{1}$ As a definition, it seems inadequate, since it covers only some instances of virtue - those that are infused rather than acquired. Accordingly, it seems reasonable to conclude with Martin Rhonheimer that the definition is one which Thomas 'presents' but 'then sets aside', because it is 'only useful for theology'.

${ }^{1}$ Peter Lombard, Sentences, 2.27.1. 
Attention to the treatment of virtue as a whole, Rhonheimer claims, shows Thomas to engage in the substantive 'rejection of this definition'. 2

It is not difficult to see why someone would interpret Thomas in this way. Given the poor fit between the definition and the acquired virtues, the easiest manner of resolving the tension is to dismiss the definition. But easy resolutions do not make for good readings. In what follows, I will show that, contrary to Rhonheimer's claim, the 'Augustinian' definition is not mentioned as a pious nod to the tradition and then set aside. Rather, close attention to the definition and its deployment is the key to discerning more clearly Thomas's intent in the questions on virtue that appear in Summa I/2.55-63.

To this end, I will proceed in four steps. In an opening section, I will propose an account of just why Thomas places the definition where he does - that is, at the end of question 55. Then I will go on to argue that the definition, far from being peripheral, discloses the inner logic of the treatment of virtue that runs from questions 55 to 63. Finally, I will show that, for the reader who grasps this inner logic, the conclusion drawn explicitly at question 65 - that only infused virtue is virtue simpliciter - is revealing but not surprising. The conclusion will not seem anomalous or unduly theological - as it is bound to seem to those for whom Thomas' ethics must proceed mainly along Aristotelian lines. ${ }^{3}$ Instead, it will appear as the manifest image of what is latently present in the prior questions.

\section{The strategic placement of the Augustinian definition}

Thomas places the 'Augustinian' definition near the beginning of Summa I/2's treatment consideration of virtue. To see why, it is necessary to track the dialectical motion of its first question. The aim of question 55 is to

${ }^{2}$ Martin Rhonheimer, The Perspective of Morality: Philosophical Foundations of Thomistic Virtue Ethics, tr. Gerald Malsbary (Washington, DC: Catholic University of America Press, 2011), pp. 197-8, n. 18.

3 Five years ago, Eleonore Stump remarked that 'scholars discussing Aquinas's ethics typically understand it as largely Aristotelian' ('The Non-Aristotelian Character of Aquinas's Ethics: Aquinas on the Passions', in Sarah Coakley (ed.), Faith, Rationality and the Passions (Malden, MA: Wiley-Blackwell, 2012), p. 91), citing Irwin, McInerny and Kenny as examples. Her remark still rings true today. One should note, however, that some readers had laid stress on the non-Aristotelian aspects of his ethics years before (e.g. Mark Jordan, On the Alleged Aristotelianism of Thomas Aquinas (Toronto: Pontifical Institute of Medieval Studies, 1992); John Inglis, 'Aquinas's Replication of the Acquired Moral Virtues: Rethinking the Standard Philosophical Interpretation of Moral Virtue in Aquinas', Journal of Religious Ethics 27 (1999), pp. 3-27). Others have since amplified and extended the non-Aristotelian reading of Thomas' ethics, particularly Andrew Pinsent, The Second-Person Perspective in Aquinas's Ethics: Virtues and Gifts (London: Routledge, 2012). 
say what virtue is, to disclose its essence. Thomas starts by indicating its genus (article 1). Virtue is a habitus, a disposition good for a human being to have. After identifying habitus as the genus of virtue, he proceeds to isolate two specific differences (articles 2-3). Only at the end of the question does Thomas consider the definition (article 4).

The primal signification of virtus, as Thomas well knows, is 'power'. The etymology's relevance should not be dismissed. Unless virtue is understood in relation to power, its character as a habitus is bound to be misunderstood. To see just how fundamental the virtue/power relation is for Thomas, consider the opening sentence of the body in each of question 55's first three articles: 'Virtue names a certain perfectio of a power' (55.1 co). 'Virtue, from the very definition of its name, denotes a certain perfectio of a power' (55.2 co). 'Virtue denotes a certain perfectio of a power' $(55.3 \mathrm{co}){ }^{4}$

To grasp virtue as a habitus, one must probe what Thomas means by the 'perfectio of a power'. In the term perfectio, the reader should simultaneously hear notes sounded by 'perfection' and 'completion'. Thomas considers the core notion of completion inseparable from the notion of an end: 'the completion of anything whatever consists chiefly in the order to its end' (55.1 co). The powers of which human virtue is the completion are powers that produce 'works of reason (opera rationis), which are proper to a human being' (55.2 ad 2). If virtue is the completion of such powers, its end must consist in productive activity. Virtue, then, cannot be just any habit, but an operative habit. Lest this conclusion seem insufficient, since not every operatio enhances a person's real strength, article 3 adds a necessary clarification: since 'every evil is an enfeeblement', as Dionysius says, the operation that stands as virtue's end must be 'good operation' (bona operatio).

Thomas' aim is to disclose the core notion of human virtue - its ratio. Articles 2 and 3 are partial symmetrical disclosures of the ratio. Their symmetry can be glimpsed by inspecting the videtur quod of both articles. For each it seems that a certain description 'does not belong to the ratio of human virtue'. In both cases, the description in question - habitus operativus in article 2, habitus bonus in article 3 - does belong to the ratio. Articles 2 and 3 thus constitute a diptych, a balanced pair whose members seem jointly to disclose the whole ratio of virtue. Were the diptych sufficient to disclose

4 All translations from the Summa into English are my own. Translations are of the Latin text as it appears in Summa theologiae, Ottawa Institute of Medieval Studies Edition, 5 vols. (Dominican College of Ottawa, 1941-45). All parenthetical references after quotations of Thomas, unless indicated otherwise, are to Summa I/2 (the Prima Secundae). Citations are to question, article and division within article (sc = 'sed contra'; co = 'body' of the article; 'ad 1' = reply to the first argument). 
virtue's whole ratio, Thomas could declare that virtue is a habitus operativus bonus, as Rhonheimer would have it, and bring question 55 to a close.

But this is precisely what he does not do. The inclusion of article 4 suggests that the whole ratio has not in fact been disclosed. Something remains - but what? Article 4 answers this question. It does so by supplying what is missing - namely, the definition of virtue that the question has been working toward. 'Virtue is a good quality of the mind, by which one lives rightly, which no one uses badly, which God works in us without us.' What does Thomas think about this definition, the only definition stricto sensu supplied by question 55? He tells us directly: 'This definition completely encompasses the whole account (tota ratio) of virtue' (55.4 co).

Each of the key terms chosen by Thomas in this assessment - the adverb perfecte, the verb complecitur, the adjective tota - stresses the definition's utter completeness. What the first portion of the question had been striving for - an articulation of virtue's essence - the definition provides. It captures not only this or that fragment; it discloses the whole ratio. Because the definition succeeds in capturing the whole account of virtue, the article in which the definition appears is rightly interpreted as the culmination of question 55, rather than an afterthought or appendix.

Why suppose that the 'Augustinian' definition captures the 'whole account' of virtue? Thomas answers: 'The complete account (perfecta ratio) of anything whatever is gathered from all of its causes. Now the aforementioned definition comprehends all the causes of virtue' (55.4 co). Virtue's formal cause is that is a 'good quality' (bona qualitas). Its material cause corresponds, first of all, to that which bears virtue: it is 'of the mind' (mentis) rather than the body. Its final cause is its good. Virtue is that 'by which one lives rightly, which no one uses badly' (qua recte vivitur, qua nullus male utitur). Finally, the definition gives its efficient cause by indicating what brings about the existence of virtue in human beings. Virtue is a quality 'which God works in us without us' (quam Deus in nobis sine nobis operatur).

\section{The definition deployed: virtue's material cause}

Thomas makes use of an Aristotelian scheme - namely, that of the 'four causes' - to explicate the Augustinian definition. That use, however, does not imply that he interprets the definition's content as Aristotelian. Before considering the definition's non-Aristotelian import, however, I want to establish decisively - against Rhonheimer and others who suppose that the definition is mentioned and then quietly disappears - that the definition in fact serves as the structuring principle of questions 55-63.

The elements of the Augustinian definition correspond to the four causes in a particular order: formal, material, final, efficient. That Thomas adopts 
this very order in the sequencing of questions 55-63 can be seen in his decision to begin with the formal cause - that is, the essence of virtue, the topic of question 55. Likewise, question 63 - the end of the sequence of questions on virtue itself, before the turn to its 'properties' - plainly concerns the efficient cause. What needs to be shown is that questions 5662 correspond to the material and the final cause. In this section, I will show that questions 56-60 correspond to the material cause. In the next, I will show that questions 61-2 correspond to the final cause.

Because virtue belongs to the mind, Thomas holds, there is no 'matter from which' (materia ex qua) it is made. Nonetheless, it may be said to have a material cause in two ways. First, every virtue has a 'matter about which' (materia circa quam) it is concerned, its own proper field or domain. Second, there is the 'matter in which' (materia in qua) the virtue resides, which Thomas identifies with its 'subject' (subiectum). Question 56, in which Thomas expressly addresses the subject of virtue, corresponds to the second of these two senses of material cause. The notion of a virtue as a 'completion of a power' demands that it be seated somewhere. The completion must be 'in that of which it is the completion' $(56.1 \mathrm{co}$ ). Any virtue, therefore, must be subjected in a power of the soul. In which powers are human virtues seated? Question 56's primary task is to address this issue. Some virtues have the intellect as their materia in qua. These are the five 'intellectual virtues' named by Aristotle. Except for prudence, they are not virtues simply speaking, because they do not satisfy the Augustinian definition's requirement that virtues cannot be badly used. By contrast to the intellectual virtues, virtues subjected in the appetitive powers are virtues, properly speaking. Any habitus that orders an appetitive power to its end and thereby completes it will be a virtue not secundum quid but simpliciter.

The same contrast between two materiae, intellect and appetite, informs question 57 on the intellectual virtues. Three of the intellectual virtues wisdom (sapientia), knowledge (scientia) and insight (intellectus) - are seated in the speculative intellect and have no necessary relation to the appetitive powers. Art likewise has no concern with the appetite as such. It cares only about 'how the work is, which it accomplishes'. It 'does not look to appetite' (57.4 co). Prudence, by contrast, does 'look to appetite' (57.4 co) and so differs from the other intellectual virtues. Beneath the art/prudence distinction is the deeper contrast between the intellective and the appetitive powers. Though prudence's subject is the intellect - otherwise it would not be an intellectual virtue - it differs from the rest of the intellectual virtues in that it essentially concerns the appetitive powers. Question 58's distinction between moral and intellectual virtue is similarly grounded in the difference between reason and appetite. 'Just as appetite is distinguished 
from reason, so moral virtue is distinguished from intellectual virtue' (58.2 co). Questions 56-8 form a unity in the general treatment of virtue. What holds these the questions together is their focus on virtue's 'material cause', construed as materia in qua.

Questions 59 and 60 move to Thomas's second sense of material cause: the 'matter about which' (materia circa quam) a virtue is concerned. To identify the material cause in this sense is the same as to discern a virtue's object: 'the materia circa quam is the object of a virtue' $(55.4 \mathrm{co})$. It is the virtue's field or domain, what the virtue is 'about'. Because the passions supply a large part of the matter for moral virtue, Thomas writes question 59 as a preliminary to question 60. Question 59 seeks to clarify the 'relation' (comparatio) between the moral virtues and the passions, fixing the scope of the materia circa quam. Question 60 proceeds to distinguish the moral virtues from one another, according to their particular matter. Just as questions 56-8 are governed by 'material cause' in the sense of materia in qua, so questions 59 and 60 correspond to 'material cause', understood as materia circa quam.

Taken as a whole, questions 56-60 correspond to the material cause. This is the second of the four causes from which Thomas says the 'whole account' (tota ratio) of virtue is gathered. Let us now move to the third cause.

\section{The Augustinian definition and virtue's final cause}

If the Augustinian definition of virtue as read by Thomas - that is, as pointing to the formal, material, final and efficient causes of virtue, in that order - is the key to the inner logic of questions 55-63, then we can expect questions $61-2$ to correspond to the final cause, and question 63 to the efficient cause. The third element of the Augustinian definition holds that virtue is a quality 'by which one lives rightly, which no one uses badly' (qua recte vivitur, qua nullus male utitur). Thomas reads this element as pointing toward virtue's final cause.

To grasp the link between questions 61-2 and the final cause, it is helpful to understand both questions as attempts to illuminate the virtues by placing them in closer relation to the ends of human life. The topic of question 61 is the cardinal or principal virtues. It begins by distinguishing between two kinds of habits according to the relation of each to usus - a clear echo of the Augustinian definition's qua nullus male utitur. Some habits confer the 'capacity (facultas) for acting well', but do not of themselves 'cause the use (usus) of a good work' $(61.1 \mathrm{co})$. Others not only confer the capacity, but also bring about something good. Habits of the first type, Thomas argues, can be called virtues only by analogy. Those of the second type, by contrast, are virtues 'according to the complete ratio of virtue'. Their power to preserve the rightness of appetite, along with the direction given to them by prudence, 
ensures their good use, and thus secures their connection to the final cause, which consists in good operation.

Each of the cardinal virtues is directed toward a good. But are they directed to the highest good? Thomas introduces this query in question 61 's closing article. Up to this point, he declares, we have considered the virtues only 'as they exist in a human being according to the condition of his nature' (61.5 co). Such virtues, notwithstanding their apparent conformity to the complete ratio of virtue, are virtues at the lowest level. They are appropriately called 'political' virtues, since they essentially belong to a person considered as animal politicum $(61.5 \mathrm{co})$. In this article, Thomas introduces a passage from Macrobius that quotes Plotinus. The passage evokes a ladder of virtues, starting from the political virtues, 'of which we have spoken until now', moving through 'cleansing virtues' (virtutes purgatoriae) and virtues in souls that have 'already been cleansed' (iam purgati animi), and culminating in 'exemplar virtues'.

Without reference to a transcendent final cause, the cardinal virtues are not fully intelligible. If one remains on the Aristotelian plane, as it were, one will have only truncated versions of the cardinal virtues - and therefore of the moral virtues as a whole, since all the other moral virtues are 'contained' under the cardinal virtues $(61.3 \mathrm{co})$. Only by heeding non-Aristotelian auctoritates about the final cause are we able to perceive the full range of cardinal virtues. Thomas starts with a 'horizontal' consideration of eleven moral virtues, distinguished by their materia in an Aristotelian fashion. As question 61 enacts the reduction of these dispositions to four principal virtues, he seems to remain on the horizontal plane. But the motion cannot remain on this plane indefinitely. It gives way to a 'vertical' motion, reaching upwards to the final cause that transcends the polis. This vertical motion opens the way to question 62's treatment of the theological virtues.

Both question 61 and question 62 are essentially about virtue's final cause, but in different ways. If question 61 most directly corresponds to the part of the Augustinian definition which stipulates that virtue is a quality 'which no one uses badly', question 62 deepens the theme that virtue is that 'by which one lives rightly' (qua recte vivitur). What it means to live rightly can for Thomas be understood only in relation to the end of human life. Question 62 begins on this very note. 'By virtue a human being is completed in relation to the acts by which she is directed to blessedness' (62.1 co). But the blessedness or happiness of a human being, Thomas adds, is duplex:

One is proportioned to human nature, namely to that which a human being can reach by the principia of her nature. The other, however, is a blessedness that surpasses the nature of a human being, to which a human 
being can reach only by divine virtue, according to a certain participation in divinity. (62.1 co)

Even in their most complete state, Thomas argues, the cardinal virtues are able to make a human being blessed only in the first sense. They are completions of 'the natural principia by which a person is directed to the connatural end - but not, however, without divine help' (62.1 co). They are utterly incapable of moving a person toward blessedness in the second sense, which Thomas calls 'supernatural blessedness' (beatitudo supernaturalis).

If a human being is to be directed toward supernatural blessedness, additional principia beyond the natural principia (and the cardinal virtues which complete them) are required. Such principia, Thomas says, are the 'theological virtues'. They have God for their object, 'so far as by them we are rightly directed (recte ordinamur) toward God' (62.1 co). An attentive reader will hear the phrase recte ordinamur as an echo of the Augustinian definition's recte vivitur. The virtues that conform most fully to this requirement of the definition and which appear at the very centre of Summa I/2's questions on virtue - are the theological virtues.

The twofold character of the final cause is the deepest ground of the distinction between question 61 and question 62. It is also what unifies them. Questions 61 and 62 should be seen as a not-quite-symmetrical pair. Both consider the highest virtues in relation to the final cause. But the double nature of beatitudo ensures that different things will need to be said about each group of virtues. Though 'principal' in relation to the other moral virtues, the cardinal virtues are teleologically subordinated to the theological virtues. Article 2's argument sed contra signals as much: what is secundum naturam hominis is lower than what is supra naturam hominis $(62.2 \mathrm{sc})$. The object of the theological virtues, Thomas argues in the next article, is 'God himself, who is the ultimate end of things, as he surpasses the knowledge of our reason' $(62.3 \mathrm{co})$. The end of the theological virtues remains bona operatio. But to the extent that good productive activity is directed toward God, the other virtues will now be directed by charity, the highest of the theological virtues.

To be sure, the other virtues retain a relative autonomy. They are not, Thomas argues, turned into so many versions of charity, as though each of them were 'essentially' charity (62.2 ad 3). But they depend on charity, because charity directs their particular goods to the highest good. Thomas does not assert the reorientation of the virtues by charity as an abstract claim - as if it were to leave a person just as she was before. On the contrary, he says, the will is now directed to the end 'as to a certain spiritual union, by which it is in a way transformed into that end, which happens by 
charity' (62.3 co). From the perspective of question 62, anodyne phrases like 'human fulfilment' are impoverished descriptions of virtue's final cause. For a person infused with charity, the end is an ever-increasing participation in blessedness - one that asymptotically approaches deification.

\section{The definition's explicit reappearance: virtue's efficient cause}

Up to this point, I have argued that Thomas's reading of the 'Augustinian' definition of virtue - placed strategically as the culmination of question 55 on virtue's essence - informs the deep structure of the eight questions that follow. This suffices to raise a serious doubt about Rhonheimer's claim that Thomas cites the definition only to set it aside. Nonetheless, Rhonheimer could reply that the definition itself is not quoted within these questions. Any such appeal, however, crashes upon the reef of question 63, where Thomas again invokes the definition explicitly.

Virtue is a quality 'which God works in us without us' (quam Deus in nobis sine nobis operatur). This last clause of the Augustinian definition, Thomas tells us, points to the efficient cause. Addressing the 'cause of virtue' (causa virtutis), question 63 begins with a topic from Aristotle: are the virtues in us by nature? After defending an answer drawn from book 2 of the Ethics as 'more true' than competing responses given by Avicenna and the Platonists (article 1), Thomas proceeds to ask whether virtues are caused by the 'habituation of works' (article 2). Some of them, he says, are - namely, those directed to a good measured by the rule of human reason. But what about virtues directed to a good whose measure is divine law? Are such virtues limited to the theological virtues treated in question 62? Thomas addresses this question by asking whether any of the moral virtues are in us by divine infusion (article 3). If they are, Thomas asks, are such infused moral virtues of the same kind or species as the virtues that we acquire from works (article 4)?

This survey of question 63 is enough to show that its topic is virtue's efficient cause. If further evidence is needed, one may observe that the last clause of the Augustinian definition (quam Deus in nobis sine nobis operatur) reappears twice within the question $(63.2 \mathrm{co}, 63.4 \mathrm{sc})$. Before considering these reappearances, we must notice two significant claims that Thomas makes in question 55 about the clause's proper interpretation. First, the clause should be understood to imply that while God causes virtues in us without our action, God does not do so without our consent (55.4 ad 6). Divine infusion is not violent insertion. Second, the clause applies only to the infused virtues. 'If this little part (quae particula) be withdrawn, the rest of the definition is common to the virtues, both acquired and infused' (55.4 co). Question 55's concluding remarks leave open a series of perplexities. How 
can Thomas hold both that the Augustinian definition covers only some of the cases and that it discloses the 'whole notion' (tota ratio) of virtue? If the definition fails to cover all the cases, should it not be regarded as faulty? If it is faulty, why does he decide to reproduce and defend it? Why does he choose to structure his general treatment of virtue around it?

In question 63, Thomas begins to construct an answer to these questions. The acquired virtues are in us by nature, but only 'according to aptitude and inchoation' (63.1 co). What is naturally in us and naturally known, Thomas holds, is not virtue itself, but 'certain beginnings' (quaedam principia) of virtue. These beginnings may be compared to 'certain seminalia' - seeds or nurseries from which the virtues grow through 'habituation' (assuetudo), from human works and actions. Because of their greater naturalness, Thomas asserts, the principia are 'nobler' (nobilior) or 'higher' (altior) than the virtues that grow out of them (63.2 ad 3). But notice also that the acquired virtues are proportional to the principia, as the lower is proportional to the higher. The proportion, Thomas adds, 'does not extend beyond nature' (63.3 ad 3).

Here Thomas has begun to set up an analogy between the acquired virtues and infused moral virtues. If humans are ultimately directed to a goal beyond nature, a supernatural end, other beginnings are required. The natural seminalia are not nearly enough, precisely because they are natural.

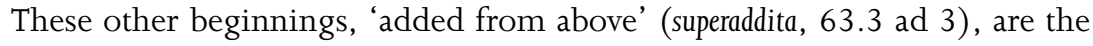
theological virtues. 'In the place of these natural principia, the theological virtues are bestowed on us by God, virtues by which we are directed to the supernatural end' (63.3 co). On the supernatural plane, the theological virtues occupy the place of the natural principia. Do we find anything that is below the theological virtues, but that proportionally corresponds to them? We do, Thomas says:

So it is necessary that to these theological virtues, there correspond proportionally other habits divinely caused in us, which other habits are related to theological virtues, as the moral and intellectual virtues are related to the natural principia of the virtues. $(63.3 \mathrm{co})$

The 'other habits divinely caused in us' are infused moral virtues. Though sufficient to direct their possessor to God without mediation, Thomas says, the theological virtues are nonetheless a 'kind of beginning' (quaedam inchoatio). The full completion of their work, which he calls their consummatio, requires other virtues that are proportioned to them. Since the direction of the human being to God does not characteristically occur without mediation, 'it is necessary that the soul is completed by other infused virtues that are about other things - yet as ordered to God' (63.3 ad 2). The Augustinian definition, it turns out, covers not only the theological virtues, 
but the entire range of virtues by which a person is effectively directed toward the supernatural end.

We are now in a position to judge the analogy - that is, a similarity inscribed within a deeper difference - between the acquired virtues and infused moral virtues. Both kinds of virtue exhibit a distinction between inchoatio and consummatio. Both feature principia that are noble in themselves, but require other habits for their completion. Such lower habits are required, so that the 'whole structure of good works rises up' - as Gregory remarks about the cardinal virtues $(61.2 \mathrm{sc})$. But the structural similarities between acquired and infused virtues cannot efface a deeper difference between them. Infused virtues, Thomas argues in article 4, differ in species from acquired virtues, because both the act and end of virtues infused by God differ from those of virtues that are humanly acquired.

Why Thomas decides to use the Augustinian definition as a map for the 'whole account' of virtue is now clear. Precisely and unproblematically, the definition covers the virtues that conform to virtue's 'complete account' (perfecta ratio). These are the infused virtues. Other virtues are also covered by the definition, but problematically, since its 'little part' (particula) about the efficient cause does not apply. The definition's problematic coverage of the acquired virtues is not a flaw in the definition, but a sign of a deeper judgement on Thomas's part. Acquired virtues, though rightly called virtues, are nonetheless virtues in a problematic sense. No matter how splendid it appears, their consummatio seems paltry when compared to the consummatio of infused virtues whose end is supernatural blessedness. If one allows Thomas' view to emerge gradually, observing the course charted by his 'four causes' reading of the Augustinian definition, one must simply reject the claim that he regards the definition as faulty. The fault lies rather in the 'incomplete' virtues that approach the perfecta ratio of virtue but do not conform to it fully.

\section{Infused virtue as virtue simpliciter}

Structured by the Augustinian definition, which Thomas defends as giving the 'whole account' (tota ratio) of virtue, Summa I/2.55-63 may be supposed to give an adequate treatment of virtue in general. But the general treatment is not quite done, since Thomas proceeds to a consideration of 'certain properties' of virtue in questions 64-67. The consideration is distributed across four questions, which treat the mean of virtues (64), their connection (65), their equality (66) and their duration (67). Questions 64-67 do not contain any startling reversals of the teachings that appear within questions 55-63. But they do offer some revealing extensions and clarifications. Unlike some later commentators who find Aristotle's theory of the mean virtually 
useless, Thomas defends the notion. But his decision to treat it as one of the 'properties' of virtue should not be taken for granted. He might, for example, have included the Aristotelian definition of virtue as a 'habit marked by choice, residing in the mean relative to us, a characteristic defined by reason and as the prudent person would define it' (Ethics 2.6, 1106b361107a2), within the sequence of questions that correspond to the 'whole account' of virtue. But he chooses not do this. Instead, he relegates the mean to the consideration of virtue's properties.

In the next question on the connection of the virtues, Thomas directly confirms a suspicion that arises from reading question 63 on the cause of virtue. As we have seen, Thomas concludes that question not by rejecting the Augustinian definition as inadequate, but rather by suggesting that humanly acquired virtues are not virtues in the full sense. What question 63 quietly suggests receives emphatic articulation in question 65, which distinguishes 'complete moral virtue' (perfecta moralis virtus) from 'incomplete moral virtue' (imperfecta moralis virtus). Incomplete moral virtues are not necessarily connected; they may be little more than natural or customary inclinations. Taken in this sense, no one virtue implies any other virtue. But if we are speaking of complete virtues, we have reason to believe that the cardinal virtues are connected. Some version of the connection, Thomas claims, is 'set down by nearly everyone' (65.1 co). It can be justified, he adds, either by reflecting on the 'general conditions of the virtues', or by examining the reciprocal interdependence of prudence and the moral virtues (65.1 co).

To assert the connection of habits that are complete moral virtues, as article 1 does, is to raise some obvious questions: Just what is a complete moral virtue? What is required of a moral virtue for its completion? Article 2 addresses these questions by pulling together some hints and clues that have been scattered throughout the treatment of virtue. Acquired moral virtues are "productive of a good as directed to an end that does not surpass the natural capacity of humanity' (65.2 co). Such virtues, Thomas holds, can be acquired without charity - as they were, he adds, by some pagans. But 'according as virtues are productive of a good as directed to the last supernatural end, they completely and truly (perfecte et vere) have the ratio of virtue; and they cannot be acquired by human actions, but are infused by God' by divine charity (65.2 co). 'Only infused virtues', Thomas now says explicitly, 'are complete (perfecta) and are called virtues simpliciter, since they direct a person well to the last end simpliciter.' 'The other virtues, namely the acquired, are virtues secundum quid' (65.2 co).

What Thomas had said earlier about the intellectual virtues (56.3) now applies to the entire range of acquired virtues, including the moral virtues. 
They are virtues only secundum quid. Commentators such as Rhonheimer, who are inclined to dismiss Thomas' quotation of the Augustinian definition, might find this result surprising or anomalous. But the reader who grasps Thomas's deployment of the Augustinian definition as a reliable guide to virtue's perfecta ratio will not be surprised by 65.2 's conclusion that humanly acquired virtues are virtues by analogy. ${ }^{5}$

To understand Thomas's treatment of virtue, one must carefully attend to his handling of the Augustinian definition, rather than crudely dismiss it. ${ }^{6}$ Without such attention, Summa I/2 on virtue is all-too-likely to appear, as Andrew Pinsent observes, as an "heterogeneous assemblage of materials from disparate sources held together in a kind of constructive tension ... a vast but imperfect aggregation of Christian materials'. ${ }^{7}$ The reading given here concurs with Pinsent's judgement, but goes beyond it by specifying more precisely the internal coherence of Summa I/2.55-63. What gives these questions their coherence, I have argued, is their tight correspondence to the four parts of the Augustinian definition, read as corresponding to the formal, material, final and efficient causes (in that order). Questions arise, of course, from taking seriously the claim that only infused virtue is virtue simpliciter. How far does the priority of infused virtue alter our understanding of acquired virtue? If someone possesses the infused virtues, to what extent does she need the acquired virtues, and why? Readers may

5 To say that humanly acquired virtues are virtues by analogy is to say that such virtues fall short of the complete or total ratio of virtue. It does not imply that such virtues are 'fake' or 'counterfeit' or 'false'. Thomas does not regard them as such.

${ }^{6}$ Another possibility is simply to ignore the Augustinian definition. David Decosimo provocatively attributes a version of this strategy to those whom he labels 'public reason Thomists', so-called from their desire to 'find a way of safely and justly navigating our pluralistic world and democratic politics by the deliverances of reason alone' (Ethics as a Work of Charity (Stanford, CA: Stanford University Press, 2014), p. 7). With Decosimo, I agree that using Thomas to find 'a solution that bears the imprimatur of Nature, the promise of Neutrality, and the unassailability of Reason' (p. 8) is bound to result in serious misreadings or distortions of the Summa. Decosimo's alternative reading, the details of which I cannot enter into here, explores the possibility that Thomas strives in multiple ways 'to be Aristotelian by being Augustinian and vice versa' (p. 9). The present argument about the structure of Summa I/2.55-63 is not, I think, entirely incompatible with Decosimo's strategy, though my reading judges Thomas to engage in a more thoroughgoing subordination of Aristotle to Augustine than he wants to allow. One can draw a contrast between 'coordinating' interpretations such as Decosimo's, where an acknowledged 'either/or' occurs within a more comprehensive 'both/and'; and 'subordinating' interpretations that acknowledge Thomas's desire to discover (or construct) 'both/and' relations between Aristotle and Augustine, while insisting that all such relations are inscribed within a more comprehensive 'either/or'.

7 Pinsent, Second-Person Perspective in Aquinas's Ethics, p. 30. 
scottish journal of theology

become frustrated, understandably, with Summa I/2's apparent lack of clear answers to such questions. As a partial antidote to such frustration, one may recall that Thomas writes Summa I/2 as a preface to Summa II/2. The point of a more attentive reading of Summa I/2.55-63 is not to answer perplexing questions about the virtues, but to enable their adequate formulation. 